\title{
Bibliometrical Analysis on Destructive Innovation Research in China
}

\author{
Xuhong XU \\ TSL School of Business \& Information Technology \\ Quanzhou Normal University \\ High Educational Engineering Research Center of \\ Fujian Province for E-Commerce Intelligent Based on \\ Cloud Computing and IOT \\ Quanzhou, China
}

\author{
Yuanren WU* \\ TSL School of Business \& Information Technology \\ Quanzhou Normal University \\ High Educational Engineering Research Center of Fujian \\ Province for E-Commerce Intelligent Based on Cloud \\ Computing and IOT \\ Quanzhou, China \\ e-mail: yuanrenwu@126.com
}

\begin{abstract}
Disruptive innovation theory has become a hot issue in the field of enterprise innovation and strategic management. Based on 627 papers for disruptive innovation field collected by journals and in China Knowledge Internet (CNKI) since 2003, analysis are made by bibliometrics. Citespace Software is applied. Quantity of issuing, key words, issuing authors and issuing authorizations for disruptive innovation research field in China are systematically reviewed and summarized in the article. Some characteristics on disruptive innovation research field in China are gained to supply reference and information to relative scholars for subsequent researches.
\end{abstract}

Keywords-disruptive innovation; bibliometrics; citespace

\section{INTRODUCTION}

In his book "The Innovator's Dilemma", after Clayton M. Christensen [1] studied in detail through the rise and fall of the disk drive, mechanical excavators and other different industries case, he put forward the concept of disruptive innovation, which powerfully explains the powerful large enterprises in technological change has been eliminated by latecomer firms. The destructive innovation target group is a secondary market or potential user, and in the main performance the introduction of products or services than the mainstream products on the market will be worse, but more simple, convenient and cheap. Because disruptive innovation has the characteristics of "low end" and uncertainty of initial return, the incumbent often neglects the disruptive innovators to obtain sufficient market development space and further change the original structure of the enterprise and gradually erode High-end market, which occupy a larger market share and plunder more profits, and ultimately dominate the market dominance [2].

In 2003, in his book "The Innovator's Solutions", Christensen further developed the theory of disruptive innovation, in which he argues that disruptive innovation involves not only technological innovation but also innovation in business models, Non-mainstream market entry, and eventually successfully subvert the mainstream market, changing the rules of competition can be called destructive innovation. On the basis of Christensen's concept of disruptive innovation, many scholars at home and abroad have studied destructive innovation from different perspectives. Many achievements have been made in the field of disruptive innovation research. There have been lots of scholars researching for disruptive innovation from different views, e.g., Liu Lixia and Bai Sheng [3] explored the development of disruptive innovation in terms of technology, market, constraints and competitive strategies, Chen Jixiang and Wang Min [4] elaborate on destructive innovation research from three aspects: the role of market management capability, the obstacles to the implementation of destructive innovation, and how to carry out destructive innovation. The above mentioned is systematical summarization and review of disruptive innovation research, which indicates a direction for development and research of disruptive innovation in China as a promotion of research. However, these comprehensive articles are just result summarizations made by the authors in certain respects with obvious one-sidedness and subjectivity so that lots of research results for disruptive innovation in China for resent years can't be reviewed in general, which probably causes deviation. After search, it is found that there is no analysis on literature for disruptive innovation research in advantage of existing bibliometrics, but bibliometrics often discovers general condition, contents and characteristic of research for certain one course or field. There has been plenty of analysis on so many courses and fields through bibliometrics, such as quantitative economics (Wu Yuanren \& Shen Lisheng, 2015) [5] and open innovation (Li Shuyan \& Sun Rui, 2016) [6]. Therefore, the existing literatures are generally reviewed and summarized by the article, and research status is mastered in order to provide reference for disruptive innovation research.

\section{DATA SOURCE AND RESEARCH METHOD}

Data in the article is derived from journals related to disruptive innovation source collected in database of CNKI, that is, on advanced search page of journal in CNKI, accurate search is made on Jan. 13, 2017 through word "disruptive innovation" in the search title for years of 2003 to 2016. 627 literatures in the journals on disruptive innovation research field in China are available. 627 effective articles are used in this article with key words, authors and issuing authorities. From lots of bibliometrics, corresponding data is gained with application of Citespace Software, which is further analyzed. Citespace Software is a visual analysis tool developed by Professor Chaomei Chen [7] of Drexel University based on 
JAVA platform, which can achieve co-citation analysis of documents, co-word analysis and collaborative analysis of institutional functions. Compared with other visualization software, the software has the advantages of more convenient data processing, better visualization effect and easier interpretation, so it can meet the requirements of cooccurrence analysis and co-occurrence analysis of large samples.

\section{EMPIRICAL ANALYSIS}

\section{A. Quantity and Trend of Issued Paper}

With analysis and statistic of the issued papers for disruptive innovation research in China, Annual quantity and distribution condition of issued papers for disruptive innovation research field are shown in Fig. 1. It indicates that issued papers have been increasing since 2003. In 2014, 80 papers are issued in peak. During 2009 to 2016, about 50 to 80 papers are basically maintained.

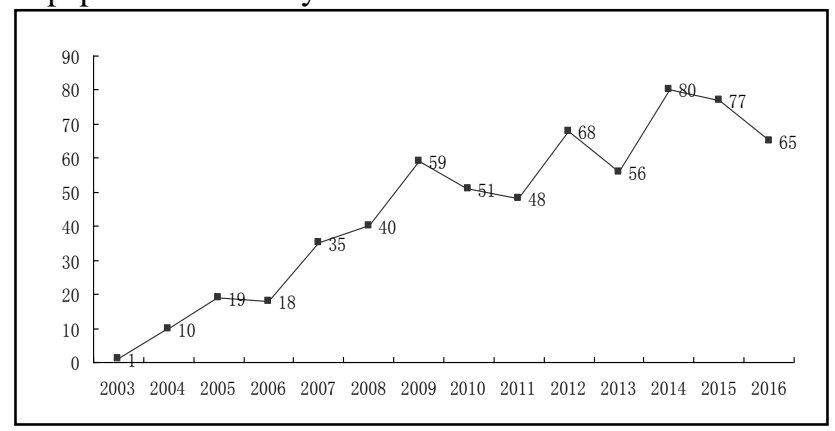

Figure 1. Quantity of issued papers for disruptive innovation research field in China since 2003

\section{B. Main Issued Journals for Disruptive Innovationt}

TABLE I. MAIN ISSUED JOURNALS FOR DISRUPTIVE INNOVATION RESEARCH FIELD IN CHINA SINCE 2003

\begin{tabular}{|c|c|c|c|}
\hline Qty. & Issued Journal & Qty. & Issued Journal \\
\hline 27 & $\begin{array}{c}\text { Twenty - first Century } \\
\text { Business Review }\end{array}$ & 8 & $\begin{array}{c}\text { Commercial Economy } \\
\text { Research }\end{array}$ \\
\hline 22 & $\begin{array}{l}\text { Science \& Technology } \\
\text { Progress and Policy }\end{array}$ & 7 & IT Manager World \\
\hline 13 & IT Time Weekly & 7 & Business (Comments) \\
\hline 12 & Chinese Entrepreneurs & 6 & $\begin{array}{l}\text { Shopping Malls } \\
\text { Modernization }\end{array}$ \\
\hline 12 & $\begin{array}{c}\text { Science and } \\
\text { Technology } \\
\text { Management Research }\end{array}$ & 6 & Business management \\
\hline 11 & $\begin{array}{l}\text { China Science and } \\
\text { Technology Forum }\end{array}$ & 5 & $\begin{array}{l}\text { Research and } \\
\text { Development } \\
\text { Management }\end{array}$ \\
\hline 11 & Business Weekly & 5 & $\begin{array}{c}\text { Sales \& Marketing } \\
\text { (Management Edition) }\end{array}$ \\
\hline 10 & Business School & 5 & Soft Science \\
\hline 8 & $\begin{array}{c}\text { Studies in Science of } \\
\text { Science }\end{array}$ & 5 & Value Engineering \\
\hline 8 & $\begin{array}{l}\text { Study of Science and } \\
\text { Management of Science } \\
\text { and Technology }\end{array}$ & 5 & $\begin{array}{c}\text { East China Economic } \\
\text { Management }\end{array}$ \\
\hline
\end{tabular}

Statistics show that since 2003, China has 20 academic journals published research papers on the field of destructive innovation more than five papers ((in Table I ). In the Graph, Journals of Twenty-first Century Business Review have published the largest quantity of papers of 27 pieces. Followed by "Science \& Technology Progress and Policy", "IT Time Weekly", "Chinese Entrepreneurs and Science", "Technology Management Research China Science and Technology Forum", "Business Weekly" and "Business School" are secondary, the above journals were equal to or more than 10 papers.

\section{Frequently Used Key Words}

Key words are usually extracted by author for the article contents. Frequently used key words and center of media for disruptive innovation research are achieved through Citespace Software in downloaded 627 papers in this section. Center of media means linkage function for certain node in the net and all nodes. Bigger center of media of key word will have effect on capacity of other key words appearing in an article simultaneously. 28 frequently used key words or the ones with high center of media for disruptive innovation research field since 2013 are displayed in Table II .

TABLE II. FREQUENTLY USED KEY WORDS FOR DISRUPTIVE INNOVATION RESEARCH FIELD IN CHINA SINCE 2003

\begin{tabular}{|c|c|c|c|c|c|}
\hline Qty. & $\begin{array}{l}\text { center } \\
\text { of } \\
\text { media }\end{array}$ & Key Words & Qty. & $\begin{array}{l}\text { center } \\
\text { of } \\
\text { media }\end{array}$ & Key Words \\
\hline 465 & 0.9 & $\begin{array}{l}\text { destructive } \\
\text { innovation }\end{array}$ & 9 & 0 & life cycle \\
\hline 39 & 0.3 & Christian & 9 & 0 & $\begin{array}{c}\text { incremental } \\
\text { innovation }\end{array}$ \\
\hline 25 & 0.1 & $\begin{array}{l}\text { sustaining } \\
\text { innovation }\end{array}$ & 9 & 0 & $\begin{array}{c}\text { business model } \\
\text { innovation }\end{array}$ \\
\hline 21 & 0.04 & $\begin{array}{c}\text { technological } \\
\text { innovation }\end{array}$ & 8 & 0.01 & innovation type \\
\hline 14 & 0.03 & innovation & 8 & 0.04 & internet of things \\
\hline 13 & 0.13 & business model & 7 & 0.03 & $\begin{array}{l}\text { everlasting } \\
\text { foundation }\end{array}$ \\
\hline 13 & 0.06 & $\begin{array}{c}\text { Business School } \\
\text { Professor }\end{array}$ & 7 & 0.03 & $\begin{array}{c}\text { people and order } \\
\text { one }\end{array}$ \\
\hline 12 & 0.21 & $\begin{array}{l}\text { entrepreneurial } \\
\text { spirit }\end{array}$ & 7 & 0.03 & $\begin{array}{c}\text { Small and } \\
\text { medium-sized } \\
\text { enterprises }\end{array}$ \\
\hline 12 & 0.07 & $\begin{array}{c}\text { competitive } \\
\text { strategy }\end{array}$ & 7 & 0.02 & Christensen \\
\hline 11 & 0.08 & $\begin{array}{l}\text { Latecomer } \\
\text { Enterprises }\end{array}$ & 7 & 0 & user experience \\
\hline 10 & 0 & $\begin{array}{c}\text { breakthrough } \\
\text { innovation }\end{array}$ & 7 & 0 & $\begin{array}{c}\text { emerging } \\
\text { technologies }\end{array}$ \\
\hline 10 & 0.1 & Clayton & 7 & 0 & Google \\
\hline 9 & 0.02 & $\begin{array}{l}\text { independent } \\
\text { innovation }\end{array}$ & 7 & 0 & $\begin{array}{c}\text { competitive } \\
\text { markets }\end{array}$ \\
\hline 9 & 0.02 & value innovation & 7 & 0 & $\begin{array}{l}\text { enterprise } \\
\text { competition }\end{array}$ \\
\hline
\end{tabular}

Viewing from Table II, the key words with high frequency of occurrence are destructive innovation, Christian, sustaining innovation, technological innovation, innovation, business model, Business School Professor, entrepreneurial spirit, competitive strategy and Latecomer Enterprises. The 
frequency of their occurrence is more than 10 times, which indicates that these are the areas most concerned by scholars. the key words with high center of media are disruptive innovation, Christian, entrepreneurial spirit, business model, sustaining innovation, Clayton et al.. Center of media for these key words reaches or surpasses 0.1 , representative research contents of which have been most fields or directions for destructive innovation since 2003. Meanwhile, In the research field of disruptive innovation, the innovation theme of sustaining innovation, technological innovation, independent innovation, value innovation, incremental innovation and business model innovation is the topic that scholars pay close attention to. The relationship between them and disruptive innovation is the focus of scholars.

\section{Analysis on Author and Authority}

1) Author with largest quantity articles for destructive innovation research

With analysis and statistic of the author for destructive innovation research in China, the authors with largest quantity articles by 627 (not less than 3 issued articles) are shown in Table III. Viewing from Table III, top three authors are $\mathrm{Wu}$ Bofan, Tan Runhua and Sun Jianguang, with not less than 9 issued articles. There are 25 authors with not less than 3 issued articles. All of them are the scholars with top largest quantity articles for destructive innovation research in China since 2003.

TABLE III. AUTHOR WITH TOP LARGEST QUANTITY ARTICLES FOR DESTRUCTIVE INNOVATION RESEARCH FIELD IN CHINA SINCE 2003

\begin{tabular}{|c|c|c|c|}
\hline Qty. & Author & Qty. & Author \\
\hline 13 & Wu Bofan & 4 & Zhang Zhengang \\
\hline 9 & Tan Runhua & 4 & Fu Liping \\
\hline 9 & Sun Jianguang & 4 & Tong Yunhuan \\
\hline 8 & Lv Rongsheng & 3 & Guo Jing \\
\hline 7 & Chen Jixiang & 3 & Zhen Weili \\
\hline 6 & Wang Bingcheng & 3 & Li Ping \\
\hline 5 & Lin Chunpei & 3 & Zhu Xinmin \\
\hline 5 & Zhang Ruimin & 3 & Xu Jiuxiang \\
\hline 5 & Kevin Kelly & 3 & Zhang Jun \\
\hline 4 & Long Jilin & 3 & Liu Baoming \\
\hline 4 & Bai Sheng & 3 & Feng Xiang \\
\hline 4 & Wang Min & 3 & $\begin{array}{c}\text { Clayton } \\
\text { Christensen }\end{array}$ \\
\hline 4 & Wang Xuhui & & \\
\hline
\end{tabular}

2) Scientific research authorities with largest quantity articles

With analysis and statistic of the scientific research authorities for disruptive innovation research in China, 16 issuing authorities for disruptive innovation research in
China with quantity of issued articles (not less than 3) are shown in Table IV.

Viewing from Table IV, it obviously indicates that Fudan University School of management is the largest amount of scientific research institutions are top authorities with 11 issued articles. In additional, top four authorities with largest quantity articles are consisted of South China University of Technology Business School, Renmin University of China Business School, Southwest University of Political Science and Management School, in total of more than 5 issued articles.

TABLE IV. AUTHORITIES WITH LARGEST QUANTITY ARTICLES FOR DISRUPTIVE INNOVATION RESEARCH IN CHINA SINCE 2003

\begin{tabular}{|c|c|c|c|}
\hline Qty. & Issuing Authorities & Qty. & Issuing Authorities \\
\hline 11 & $\begin{array}{c}\text { School of management, } \\
\text { Fudan University }\end{array}$ & 4 & $\begin{array}{c}\text { School of economics and } \\
\text { management, } \\
\text { Northwestern University }\end{array}$ \\
\hline 6 & $\begin{array}{l}\text { School of business } \\
\text { administration, South } \\
\text { China University of } \\
\text { Technology }\end{array}$ & 4 & $\begin{array}{c}\text { School of Economics and } \\
\text { Management, Tsinghua } \\
\text { University }\end{array}$ \\
\hline 5 & $\begin{array}{c}\text { School of business, } \\
\text { Renmin University of } \\
\text { China }\end{array}$ & 3 & $\begin{array}{c}\text { Hebei University of } \\
\text { Technology }\end{array}$ \\
\hline 4 & $\begin{array}{c}\text { School of management, } \\
\text { Southwest University of } \\
\text { Political Science and Law }\end{array}$ & 3 & $\begin{array}{c}\text { School of management, } \\
\text { University of Shanghai } \\
\text { for Science and } \\
\text { Technology }\end{array}$ \\
\hline 4 & $\begin{array}{c}\text { Department of } \\
\text { management and } \\
\text { economics, Tianjin } \\
\text { University }\end{array}$ & 3 & $\begin{array}{c}\text { School of economics and } \\
\text { management, Civil } \\
\text { Aviation University of } \\
\text { China }\end{array}$ \\
\hline 4 & $\begin{array}{c}\text { University of } \\
\text { International Business } \\
\text { and Economics } \\
\text { International Business } \\
\text { School }\end{array}$ & 3 & $\begin{array}{c}\text { Haier group board } \\
\text { management of Shanghai } \\
\text { Jiao Tong University }\end{array}$ \\
\hline $\begin{array}{c}\text { School of business } \\
\text { administration, Dongbei } \\
\text { University of Finance and } \\
\text { Economics }\end{array}$ & 3 & $\begin{array}{c}\text { School of economics, } \\
\text { Huazhong University of } \\
\text { Science and Technology }\end{array}$ \\
\hline
\end{tabular}

\section{CONCLUSION}

Some characteristics for disruptive innovation research in China are gained analyzed through bibliometrics based on the key words, authors and issuing authorities mentioned in 627 papers issued in journals. The research indicates that research contents represented by disruptive innovation, Christine, sustaining innovation, technological innovation, innovation, business model, business school professors, entrepreneurial spirit, competitive strategy, latecomer firms are most fields or directions for disruptive innovation since 2003. Wu Bofan, Tan Runhua, and Sun Jianguang Wu Bofan, Tan Runhua, and Sun Jianguang are top three authors with largest quantity articles in research field of disruptive innovation in China. Fudan University School of Management, South China University of Technology School 
of Business Administration, Renmin University of China Business School, Southwest University of Political Science and Law School of Management are top four issuing authorities for disruptive innovation research in China.

\section{ACKNOWLEDGMENT}

This research was financially supported by JK Class Project of Fujian Provincial Education Department "Research on the Impact Mechanism of Comprehensive Consumer Experience of Mobile Shopping on Repurchase Intention" (Grant NO. JAS161048). Corresponding author is Yuanren Wu. E-mail: yuanrenwu@126.com.

\section{REFERENCES}

[1] Christensen C M, The Innovator's Dilemma: When New Technologies cause greatfirms to fail. Boston, MA: Harvard Business School Press.
[2] Christensen C M, The Innovator's Solution: Creating and Sustaining Successful Growth. Boston, MA: Harvard Business School Press.

[3] Liu Lixia, Bai Sheng, "A Summary of the Theory of Destructive Innovation", Journal of Business Economics, vol.29, pp.91-92, 2012.

[4] Chen Jixiang, Wang Min, "A Summary of the Latest Research on Destructive Innovation Theory", Science \& Technology Progress and Policy, vol.11, pp.155-160, 2009.

[5] Wu Yuanren, Shen Lisheng, "A Study on Knowledge Map of Quantitative Economics in China: Bibliometric Analysis Based on CSSCI (2000-2014) ," Data Economic Dynamics,vol.8, pp.84-96, 2015.

[6] Li Shuyan, Sun Rui, "Analysis of Foreign Open Innovation Schools Based on the Author Co-citation Analysis," Science Research Management, vol.5, pp.10-18, 2016.

[7] Chen Chaomei, "Citespace II: Detecting and visualizing emerging trends and transient patterns in scientific literature", Journal of the China Society for Scientific and Technical information, vol.3, pp.401421, 2009. 